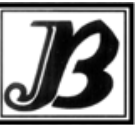

J. bio-sci. 17: 13-20, 2009

ISSN 1023-8654

http://www.banglajol.info/index.php/JBS/index

\title{
DISTRIBUTION OF MOTILE AEROMONADS, PSEUDOMONADS AND OXYTETRACYCLINE RESISTANT BACTERIA IN FRESHWATER CATFISH, PANGASIUS PANGASIUS HATCHERIES OF WEST BENGAL, INDIA
}

\author{
T Jawahar Abraham*, G Bharathkumar \\ Department of Fishery Pathology and Microbiology, Faculty of Fishery Sciences, \\ West Bengal University of Animal and Fishery Sciences, Kolkata - 700 094, West Bengal, India
}

\begin{abstract}
Context: Understanding the distribution of different groups of bacteria and their role in the hatchery production of catfishes is important for the implementing of appropriate disease control strategies and sustainable production.

Objectives: The aim was to study the distribution of total viable bacteria, motile aeromonads, pseudomonads and oxytetracycline (OTC) resistant bacteria in Pangasius pangasius hatcheries of West Bengal, India.

Materials and Methods: Following standard methods, quantification of total viable counts (TVCs) on tryptic soy agar (TSA), motile aeromonads on starch ampicillin agar, pseudomonads on Pseudomonas isolation agar and antibiotic resistant bacteria on TSA supplemented with OTC at $25-\mu \mathrm{g} / \mathrm{ml}$ was done from fertilized eggs, hatching pool water, larvae, larval rearing water and source water collected in three $P$. pangasius hatcheries in West Bengal, India.
\end{abstract}

Results: The hatching pool water had high levels of TVCs and motile aeromonads than in source water. The magnitude of increase in the levels of TVCs and motile aeromonads in hatching pool water was to the tune of 2 to 3 log units than in source water. The mean counts of viable bacteria, motile aeromonads, pseudomonads and OTC resistant bacteria recorded on fertilized $P$. pangasius eggs were $\log 5.48 \pm 0.28$ /egg, log $4.11 \pm 0.29$ legg, $\log 3.32 \pm 0.35$ legg and $\log 4.50 \pm 0.56$ legg, respectively. In larvae the counts were $\log 6.58 \pm 0.31 / \mathrm{g}$ and $\log 5.36 \pm 0.23 / \mathrm{g}$, $\log 4.34 \pm 0.20 / \mathrm{g}$ and $\log 5.74 \pm 0.22 \mathrm{gg}$ respectively for viable bacteria, motile aeromonads, pseudomonads and OTC resistant bacteria. The OTC resistant bacteria were ranged from 0.91 to $24.29 \%, 5.12$ to $22.67 \%$ and 11.49 to $20.83 \%$ of TVCs in water, eggs and larvae, respectively. Significant differences existed among the OTC resistant bacteria between eggs and larvae, and larval rearing water and larvae.

Conclusion: The results of this study suggest that there is an urgent need on the prudent use of antibiotics in pangasid catfish hatcheries and to control the bacterial flora by other means.

Key words: Catfish hatchery, Pangasius pangasius, Aeromonads, Pseudomonads, Oxytetracycline resistant bacteria

\section{Introduction}

Aquaculture is one of the fastest developing growth sectors in the world and Asia presently contributes about $90 \%$ to the global production. In India, the State West Bengal is the pioneer in freshwater fish seed production, which contributes about $75 \%$ of the India's fish seed production. The fish seed production of this State has increased from 2,300 millions in 1980-1981 to 13,572 millions in 2007-08 (Bhattacharya 2008). There are about 573 fish hatcheries in West Bengal and majority of which are located in 24 Parganas (North) and Bankura districts. Nearly $70 \%$ of the 200 hatcheries located in 24 Parganas (North) district produce

${ }^{*}$ Corresponding author 
Indian major and exotic carp seeds along with either catfishes or minor carps. Rest of the hatcheries of this district are involved in the breeding and production of seeds of catfishes namely Clarias batrachus, $C$. gariepinus, C. macrocephalus, Pangasius pangasius, P. sutchi, etc because of good market value, high profitability and easy management practices. Captive breeding of pangasids such as yellowtail cattish or pangas (Pangasius pangasius) and sutchi catfish (P. sutchi) in West Bengal using carp pituitary extract (Chattopadhyay, 2003) and ovaprim (Sarkar et al. 2006) have been reported. Prevalence of diseases in Pangasius spp. (Dang et al. 2007, Mallick 2008) and association of bacterial pathogens in frozen fillets of aquacultured Pangasius have also been documented (MAF 2008) due to the intensification in catfish culture. The reports on the distribution of different bacteria and their role in the hatchery production and larval rearing of pangasid catfishes are, however, scanty. The present communication reports the bacteriology of eggs and larvae of yellowtail catfish, $P$. pangasius and the environment.

\section{Materials and Methods}

Samples and location of the sampling area: The study was carried out during the peak-breeding season between March 2007 and August 2007. Five each of samples comprising fertilized eggs, hatching pool water, larvae and larval rearing water and source water $(n=3)$ were collected separately from three $P$. pangasius hatcheries in Naihati, 24 Parganas (North) district, West Bengal, India.

Commercial antibiotics: Commercial antibiotics such as oxytetracycline (OTC) capsule I.P (Pfizer Ltd., NaviMumbai) and ampicillin (Lyke, Hetero Health Care Ltd., Mumbai) were procured locally. Stock antibiotic solutions were prepared by dissolving appropriate concentration of respective antibiotic in sterile physiological saline. Working solutions were prepared using sterile saline as and when required.

Collection of samples: Water samples were collected aseptically in $300 \mathrm{ml}$ capacity sterilized glass containers. Viable developed eggs (fertilized eggs) and larvae were collected and packed in U-V sterilized oxygen-filled polythene bags. The samples were placed in an insulated container and brought to the laboratory within 2-3 $\mathrm{h}$ of collection.

Bacteriology: The water samples were diluted by 10 fold serial dilution in physiological saline to appropriate levels and used for the enumeration of total viable counts, motile aeromonads, presumptive pseudomonads and OTC resistant bacteria immediately on reaching the laboratory. The bacterial counts are presented as colony forming units (cfu)/ml of water

The bacterial flora of viable fertilized eggs was enumerated by the method of Huys et al. (2001) with little modification. Briefly, the medium containing fertilized eggs in polythene bags was first filtered through sterilized plankton net having a pore size of $10 \mu \mathrm{m}$ to separate the eggs from the suspending medium. Ten numbers of unwashed eggs were aseptically collected and transferred to sterile test tube containing $10 \mathrm{ml}$ sterile saline solution. The eggs were macerated to fine paste with a sterile glass rod and thoroughly vortexed, diluted by 10 fold serial dilution in saline to appropriate levels and used for the bacterial enumeration immediately. The bacterial counts are presented as cfu/egg.

The bacterial flora associated with the $P$. pangasius larvae were enumerated as described in Blanch et al. (1997). The larvae were aseptically cut in to small pieces by using a sterile scissor. Ten grams of cut pieces of larvae, weighed aseptically in an electronic balance, was transferred to $90 \mathrm{ml}$ of saline and homogenized thoroughly in a homogenizer. The homogenized larval samples were diluted by 10 fold serial dilution in saline to appropriate levels and used for the enumeration of bacteria immediately. The bacterial counts are presented as cfu/g larvae.

The bacterial groups enumerated following standard methodology (APHA 1992) include total viable counts (TVCs), motile aeromonads counts (MACs), presumptive pseudomonads counts (PPCs) and antibiotic 
(oxytetracycline) resistant bacterial counts (ARBCs). Aliquots (0.1 $\mathrm{ml}$ each) of appropriately diluted larvae, eggs and water samples were spread on to tryptic soy agar (TSA) for TVCs, starch ampicillin agar (SAA) (Palumbo et al. 1985) for MACs, Pseudomonas isolation agar (PIA) for PPCs and TSA supplemented with OTC at $25-\mu \mathrm{g} / \mathrm{ml}$ for ARBCs in duplicate. All plates were incubated at room temperature $\left(30 \pm 2^{\circ} \mathrm{C}\right)$ for 24 $48 \mathrm{~h}$ and the colonies counted. The seeded SAA plates after $24 \mathrm{~h}$ of incubation were flooded with iodine solution. The ampicillin resistant, amylase positive and yellow colonies were counted as presumptive motile aeromonads. Besides, a series of biochemical reactions as described by Lechevallier et al. (1980) were performed to identify Aeromonas and Pseudomonas. Collins et al. (1989) was consulted for biochemical tests. The results of the bacterial counts were processed by log transformation. Student - ' $\mathrm{t}$ ' test was carried out using Microsoft Excel Package.

\section{Results}

The hatchery source water contained TVCs, MACs, PPCs and ARBCs in the range of $5.50 \times 10^{3}-2.35 \times 10^{4}$ $/ \mathrm{ml}, 1.50 \times 10^{2}-4.70 \times 10^{3} / \mathrm{ml},<1 \times 10^{1}-7.0 \times 10^{1} / \mathrm{ml}$ and $5.0 \times 10^{1}-6.50 \times 10^{2} / \mathrm{ml}$, respectively. The distribution of these bacterial groups in $P$. pangasius eggs, hatching pool water, larvae and larval rearing water are presented in Tables 1-2 and Fig. 1. The TVCs were recorded in the range of $7.00 \times 10^{5}-5.20 \times 10^{6} / \mathrm{ml}$ in hatching pool water with a mean value of log6.19 $\pm 0.34 / \mathrm{ml}$. The MACs and PPCs ranged between $2.10 \times 10^{4}$ and $1.10 \times 10^{5} / \mathrm{ml}(\log 4.72 \pm 0.29 / \mathrm{ml})$ and, $1.70 \times 10^{2}$ and $3.50 \times 10^{3} / \mathrm{ml}(\log 2.87 \pm 0.59 / \mathrm{ml})$. The levels of OTC resistant bacteria in hatching pool water were observed to be in the range of $4.70 \times 10^{4}-1.90 \times 10^{5} / \mathrm{ml}$ with a mean of $\log 5.05 \pm 0.28 / \mathrm{ml}$. The fertilized $P$. pangasius eggs had TVCs and MACs in the range of 1.25 $\times 10^{5}-7.00 \times 10^{5}$ legg $(\log 5.48 \pm 0.28$ legg $)$ and $5.50 \times 10^{3}-3.50 \times 10^{4} /$ egg $(\log 4.11 \pm 0.29$ legg), respectively. The PPCs were in the range of $5.20 \times 10^{2}-4.00 \times 10^{3} / \mathrm{egg}$ (log3.32 \pm 0.35 /egg). The counts of OTC resistant bacteria ranged from $6.40 \times 10^{3}$ to $1.55 \times 10^{5} / \mathrm{egg}$ with a mean of $\log 4.50 \pm 0.56$ /egg.

The levels of TVCs and MACs in P. pangasius larval rearing water recorded were $5.25 \times 10^{5}-1.20 \times 105 / \mathrm{ml}$ $(\log 5.87 \pm 0.14 / \mathrm{ml})$ and $2.05 \times 10^{4}-1.20 \times 10^{5} / \mathrm{ml}(\log 4.62 \pm 0.28 / \mathrm{ml})$, respectively. The PPCs ranged between $1.00 \times 10^{3}$ and $3.50 \times 10^{3} / \mathrm{ml}(\log 3.26 \pm 0.21 / \mathrm{ml})$; while the OTC resistant bacteria recorded in larval rearing water were in the range of $3.50 \times 10^{4}-1.60 \times 10^{5} / \mathrm{ml}$ with a mean of $\log 5.96 \pm 0.37 / \mathrm{ml}$. The $P$. pangasius larvae recorded TVCs and MACs in the range of $1.20 \times 10^{6}-7.00 \times 10^{6} / \mathrm{g}(\log 6.58 \pm 0.31 / \mathrm{g})$ and $1.00 \times 10^{5}-4.10 \times 10^{5} / \mathrm{g}(\log 5.36 \pm 0.23 / \mathrm{g})$, respectively. The PPCs ranged between $1.00 \times 10^{4}$ and $3.30 \times$ $10^{4} / \mathrm{g}(\log 4.34 \pm 0.20 / \mathrm{g})$. The OTC resistant bacteria were recorded in the range of $2.50 \times 10^{5}-9.00 \times 105 / \mathrm{g}$ with a mean of $\log 5.74 \pm 0.22 \mathrm{gg}$ larvae (Table 2 and Fig. 1). The significance of differences in the counts of bacteria of various samples is presented in Table 3.

The proportion of motile aeromonads, presumptive pseudomonads and OTC resistant bacteria in the TVCs of different samples of $P$. pangasius hatcheries are depicted in Figs. 2-4. The proportion of MACs in the TVCs of hatching pool water, eggs larval rearing water and larvae ranged from $1.30-7.89 \%, 3.00-5.00 \%, 2.93-$ $9.60 \%$, and $3.14-12.62 \%$, respectively. The proportion of MACs was higher in larvae followed by larval rearing water, eggs and hatching pool water (Fig. 2). The proportion of PPCs in the TVCs was much lower than the MACs and it ranged between 0.017 and $0.16 \%$ in hatching pool water, 0.10 and $0.87 \%$ in eggs, 0.14 and $0.67 \%$ in larval rearing water, and 0.40 and $0.83 \%$ in larvae. The proportion was higher in larvae followed by eggs, larval rearing water and hatching pool water (Fig. 3). The proportion of OTC resistant bacteria in the TVCs was observed to be in the range of $3.36-24.29 \%, 5.12-22.67 \%, 4.86-12.80 \%$ and $11.49-20.83 \%$, respectively in hatching pool water, eggs, larval rearing water and larvae. High proportion of OTC resistant bacteria was noticed in larvae followed by eggs (Fig. 4). 
Table 1. Counts of total viable bacteria, motile aeromonads, presumptive pseudomonads and antibiotic resistant bacteria in Pangasius pangasius hatching pool water and eggs

\begin{tabular}{lcccc}
\hline $\begin{array}{c}\text { Sample: } \\
\text { Hatching pool water }\end{array}$ & $\begin{array}{c}\text { Total viable } \\
\text { Bacteria, } \\
\text { Count/ml }\end{array}$ & $\begin{array}{c}\text { Motile aeromonads } \\
\text { Count/ml }\end{array}$ & $\begin{array}{c}\text { Presumptive } \\
\text { pseudomonads } \\
\text { Count/ml }\end{array}$ & $\begin{array}{c}\text { OTC resistant bacteria, } \\
\text { Count/ml }\end{array}$ \\
\hline H1: Sample 1 & $5.20 \times 10^{6}$ & $6.75 \times 10^{4}$ & $2.00 \times 10^{3}$ & $1.75 \times 10^{5}$ \\
H1: Sample 2 & $7.00 \times 10^{5}$ & $3.20 \times 10^{4}$ & $1.70 \times 10^{2}$ & $1.70 \times 10^{5}$ \\
H2: Sample 3 & $2.20 \times 10^{6}$ & $1.10 \times 10^{5}$ & $3.50 \times 10^{3}$ & $1.90 \times 10^{5}$ \\
H2: Sample 4 & $1.20 \times 10^{6}$ & $2.10 \times 10^{4}$ & $2.00 \times 10^{2}$ & $4.70 \times 10^{4}$ \\
H3: Sample 5 & $9.50 \times 10^{5}$ & $7.50 \times 10^{4}$ & $1.00 \times 10^{3}$ & $6.50 \times 10^{4}$ \\
\hline Fertilized eggs & Count/egg & Count/egg & Count/egg & Count/egg \\
\hline H1: Sample 1 (10) & $3.45 \times 10^{5}$ & $1.50 \times 10^{4}$ & $3.00 \times 10^{3}$ & $7.80 \times 10^{4}$ \\
H1: Sample 2 (12) & $7.00 \times 10^{5}$ & $3.50 \times 10^{4}$ & $4.00 \times 10^{3}$ & $1.55 \times 10^{5}$ \\
H2: Sample 3 (12) & $4.00 \times 10^{5}$ & $1.20 \times 10^{4}$ & $3.20 \times 10^{3}$ & $3.00 \times 10^{4}$ \\
H2: Sample 4 (10) & $1.25 \times 10^{5}$ & $5.50 \times 10^{3}$ & $5.20 \times 10^{2}$ & $6.40 \times 10^{3}$ \\
H3: Sample 5 (11) & $2.10 \times 10^{5}$ & $1.00 \times 10^{4}$ & $2.00 \times 10^{3}$ & $1.35 \times 10^{4}$ \\
\hline Values in parenthesis are the age of eggs in hour; H: Hatchery & &
\end{tabular}

Table 2. Counts of total viable bacteria, motile aeromonads, presumptive pseudomonads and antibiotic resistant bacteria in Pangasius pangasius larval rearing water and larvae

\begin{tabular}{lcccc}
\hline $\begin{array}{c}\text { Sample: } \\
\text { Larval rearing water }\end{array}$ & $\begin{array}{c}\text { Total viable bacteria } \\
\text { Count/ml }\end{array}$ & $\begin{array}{c}\text { Motile aeromonads } \\
\text { Count/ml }\end{array}$ & $\begin{array}{c}\text { Presumptive } \\
\text { pseudomonads } \\
\text { Count/ml }\end{array}$ & $\begin{array}{c}\text { OTC resistant bacteria, } \\
\text { Count/ml }\end{array}$ \\
\hline H1: Sample 1 & $1.25 \times 10^{6}$ & $1.20 \times 10^{5}$ & $2.20 \times 10^{3}$ & $1.60 \times 10^{5}$ \\
H1: Sample 2 & $7.20 \times 10^{5}$ & $3.10 \times 10^{4}$ & $1.00 \times 10^{3}$ & $3.50 \times 10^{4}$ \\
H2: Sample 3 & $6.35 \times 10^{5}$ & $4.20 \times 10^{4}$ & $2.00 \times 10^{3}$ & $4.25 \times 10^{4}$ \\
H2: Sample 4 & $7.00 \times 10^{5}$ & $2.05 \times 10^{4}$ & $1.30 \times 10^{3}$ & $8.70 \times 10^{4}$ \\
H3: Sample 5 & $5.25 \times 10^{5}$ & $4.15 \times 10^{4}$ & $3.50 \times 10^{3}$ & $3.75 \times 10^{4}$ \\
\hline Larvae & Count/g & Count/g & Count/g & Count/g \\
\hline H1: Sample 1 (7) & $6.25 \times 10^{6}$ & $2.20 \times 10^{5}$ & $2.50 \times 10^{4}$ & $8.00 \times 10^{5}$ \\
H1: Sample 2 (2) & $1.20 \times 10^{6}$ & $1.00 \times 10^{5}$ & $1.00 \times 10^{4}$ & $2.50 \times 10^{5}$ \\
H2: Sample 3 (11) & $4.35 \times 10^{6}$ & $3.20 \times 10^{5}$ & $2.50 \times 10^{4}$ & $5.00 \times 10^{5}$ \\
H2: Sample 4 (9) & $7.00 \times 10^{6}$ & $2.20 \times 10^{5}$ & $3.30 \times 10^{4}$ & $9.00 \times 10^{5}$ \\
H3: Sample 5 (8) & $3.25 \times 10^{6}$ & $4.10 \times 10^{5}$ & $2.50 \times 10^{4}$ & $5.50 \times 10^{5}$ \\
\hline Values in parenthesis are the age of larvae in days; H: Hatchery; OTC: Oxytetracycline & &
\end{tabular}

Table 3. Significance of difference (t-values) in bacterial counts among the samples of catfish Pangasius pangasius hatchery

\begin{tabular}{llcc}
\hline \multicolumn{1}{c}{ Variable 1 } & Variable 2 & $\mathrm{t}$ - stat $(\mathrm{df}=8)$ & Level of significance \\
\hline Total plate count & & -3.560 & \\
Hatching pool water & Egg & -5.829 & $\mathrm{P}<0.007$ \\
Egg & Larvae & 4.679 & $\mathrm{P}<0.0004$ \\
Larval rearing water & Larvae & & $\mathrm{P}<0.002$ \\
Motile aeromonads count & & -3.288 & \\
Hatching pool water & Egg & -7.515 & $\mathrm{P}<0.01$ \\
Egg & Larvae & 4.479 & $\mathrm{P}<0.0001$ \\
Larval rearing water & Larvae & 1.459 & $\mathrm{P}<0.002$ \\
$\begin{array}{l}\text { Presumptive pseudomonads count } \\
\text { Hatching pool water }\end{array}$ & Egg & -5.629 & $\mathrm{P}>0.05$ \\
Egg & Larvae & 8.389 & $\mathrm{P}<0.0005$ \\
Larval rearing water & Larvae & -1.952 & $\mathrm{P}<0.0001$ \\
Oxytetracycline resistant bacterial count & & -4.632 & $\mathrm{P}>0.05$ \\
Hatching pool water & Egg & 6.007 & $\mathrm{P}<0.002$ \\
Egg & Larvae & & $\mathrm{P}<0.0003$ \\
\hline Larval rearing water & Larvae & &
\end{tabular}




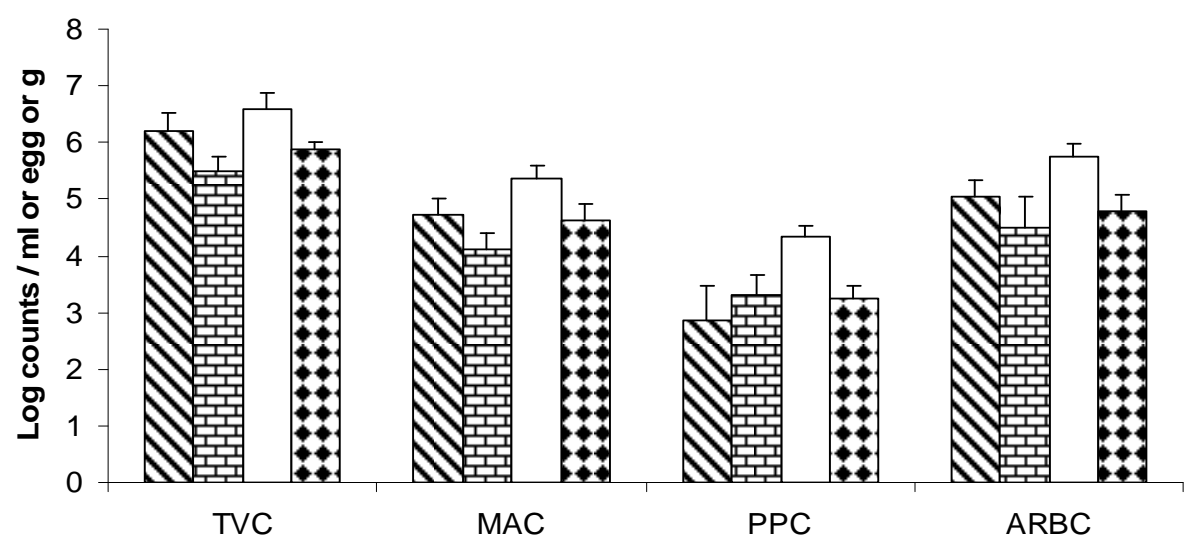

$\mathbf{\Delta H P W} \boldsymbol{g}$ Eggs $\square$ Larvae $\mathbf{\mathrm { LRW }}$

HPW: Hatching pool water; LRW: Larval rearing water; TVC: Total viable bacterial counts; MAC: Motile aeromonads count; PPC: Presumptive pseudomonads count; ARBC: Antibiotic (oxytetracycline) resistant bacterial count.

Fig. 1. Mean counts of bacteria in Pangasius pangasius hatchert samples

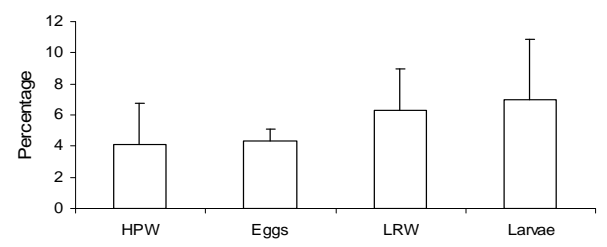

HPW: Hatching pool water; LRW: Larval rearing water

Fig. 2. Proportion of motile aeromonads in the total viable counts.

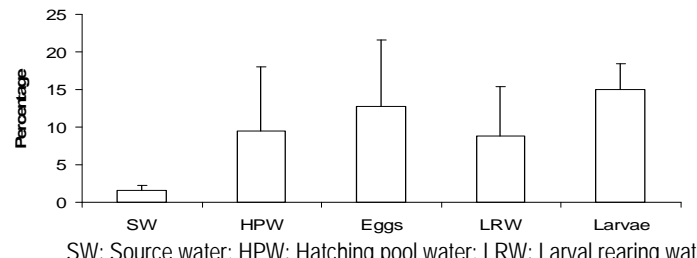

SW: Source water; HPW: Hatching pool water; LRW: Larval rearing water

Fig. 3. Proportion of oxytetracycline resistant bacteria in the total viable counts.

\section{Discussion}

Pangasius pangasius and $P$. sutchi were introduced in to the West Bengal farming system from Thailand through Bangladesh in 1994-95 and established their importance as profitable species in aquaculture. Prior to breeding, $P$. pangasius brooders were conditioned and fed twice daily with farm-made feed containing cereal waste (25\%), broken rice (25\%), rice bran (20\%), mustard oil cake (15-20\%) and animal meat (10$15 \%$ ) as the main food components at $5 \%$ of total body weight. Induced breeding was followed as described in Chattopadhyay (2003). As shown in Table 1 and Fig. 1, the hatching pool water with fertilized pangas eggs contained high levels of bacteria. The magnitude of increase in the levels of TVCs and MACs in hatching pool water was to the tune of $2-3 \log$ units than in source water. Also the TVCs of hatching pool varied among hatcheries. This could be attributed to the practice of treating the fertilized eggs with milk solution, i.e., $200 \mathrm{ml}$ milk $/ 30$ liter water, following stripping and fertilization to remove the adhesive gelatinous layer, for $20 \mathrm{~min}$ and subsequent transfer to Chinese hatchery. The interactions between bacteria and the biological surfaces during the incubation and hatching of eggs and rearing of larvae may result in the formation of an indigenous bacterial flora. Although the bacterial flora that develop on the egg surface and their diversity are the reflection of the bacterial composition of water, Hansen and Olafsen (1999) reported that species-specific adhesion to surface receptors may affect the composition of the epiflora. The differences in the viable counts of hatching pool water and eggs to the tune of about one log unit were significant. The differences in PPCs and ARBCs of eggs and hatching pool water were, however, 
insignificant. The incubation of eggs at high densities, often resulting in eggs overgrown by bacteria, may affect the bacterial association and/or lead to shift in bacterial association which hamper egg development and subsequently affect hatching, larval survival. Bacterial colonisations reportedly have adverse effects or protective effects on eggs and on the developing embryo (Olafsen 2001). Despite the high levels of bacteria in egg incubation environment, the present study observed $80-86 \%$ fertilization rate and about $90 \%$ hatching rate within $24 \mathrm{~h}$ of fertilization, thus, signifying the overall well being of the pangas hatchery system in West Bengal.

During larval rearing the food is added at high concentration to water, which results in an excellent medium for the growth of bacteria. The pangas hatchlings of the present study were fed with lactogen, a powdered infant food, for the first $48 \mathrm{~h}$ followed by earthworm powder thrice daily for up to 8 days and thereafter with soyabean dust until stocking in rearing ponds. The newly hatched larvae normally live in close contact with egg shells and debris, and acquire bacteria from them. Fish hatchlings and larvae also ingest bacteria by drinking and feeding and, thus, the formation of intestinal bacterial flora. Unlike the eggs, the pangas larvae recorded high counts of TVCs $(P<0.002)$, MACs $(P<0.002)$, PPCs $(P<0.0001)$ and ARBCs $(P<0.0003)$ than in rearing water. The differences in the counts of these bacteria in hatching pool water and larval rearing water was insignificant $(P<0.05)$. There existed significant differences between the TVCs of eggs and hatching pool water $(P<0.007)$, and eggs and larvae $(P<0.0004)$. Significant differences were also seen between the MACs $(P<0.0001)$ and PPCs $(P<0.0005)$ of eggs and larvae. Similar to this study, Hansen and Olafsen (1989) reported a 1000- fold increase in bacterial counts of the ambient water through hatching. Nevertheless, the differences in the TVCs, MACs, PPCs and ARBCs of hatching pool and larval rearing waters (Table 3 ) were insignificant $(P>0.05)$.

The aeromonad and pseudomonad groups comprise microorganisms with a dynamic role in the freshwater environments. They are isolated from water, sediment, plankton, invertebrates, and fish, and are natural constituents of the bacterial flora of the digestive tract of aquatic animals (Austin and Austin 2007) including mollusks, which form the primary food at various life stages of pangas (Sarkar et al. 2006). The proportions of motile areomonads, pseudomonds and OTC resistant bacteria were observed to be high on eggs and larvae than in water samples. A marked change in the bacterial population with age and feed intake was observed, as revealed in their proportions in larvae and larval rearing water compared to eggs and hatching pool water (Figs. 2-4). There have been reports on the isolation of bacteria from slime, external surfaces and intestine and their composition may change with age, nutritional status, and environmental conditions (Sugita et al. 1991, Hansen and Olafsen 1999, Olafsen 2001).

The present study isolated OTC resistant bacteria ranging from 3.36 to $24.29 \%$ in water and 5.12 to $22.67 \%$ on eggs and 11.49 to $20.83 \%$ in larvae (Fig. 4, Tables 1 and 2), because of the use of OTC and terramycin both in feed and water in concentrations ranging from 2 to $15 \mathrm{ppm}$ in various stages of pangas production as prophylactic and curative measures in all the hatcheries. The fact is that source water also harboured OTC resistant bacteria in the range of $0.91-2.55 \%(1.52 \pm 0.73 \%)$ of TVCs, although much lower than the levels noted in hatching pool and larval rearing water. The results further indicated the prevalence of OTC resistance among the normal bacterial flora of water drawn for hatchery operations and high incidence of OTC resistant bacteria with age or the quantum of antibiotic use as there were differences in ARBCs between eggs and larvae, and larval rearing water and larvae. The difference in the OTC resistant bacterial counts of eggs and hatching pool water was, however, insignificant $(P>0.05)$. There is also a possibility of increase in antibiotic resistant bacteria due to aquaculture activities such as addition of organic materials, degradation of feed wastes and introduction of bacteria from enteric tracts as suggested by Husevaq et al. 
(1991). The study by Subagja et al. (1999) demonstrated that the survival rates of hatchery raised $P$. hypophthalmus larvae were systematically improved when rearing was carried out in water containing OTC at a dose of 5-20 mg/l. On the other hand, Verner-Jeffreys et al. (2004) reported that addition of OTC, oxolinic acid and amoxycillin at $20 \mathrm{mg} / \mathrm{l}$ may improve the survival of yolk-sac Atlantic halibut, Hippoglossus hippoglossus L. larvae and but suppress the gut microflora at this stage of development. The results of the present study corroborate the observation of Kha (2006) who reported the prevalence of OTC resistance in over $90 \%$ of the bacterial isolates in Pangasius culture systems of Vietnam that used OTC. High resistance to OTC in Edwardsiella ictaluri isolated from diseased freshwater catfish, $P$. hypophthalmus in Vietnam was also reported (Dang et al. 2007). Use of antibiotics in aquaculture facilities may result in alterations in the microflora that could be unfavourable (Hansen et al. 1992, Verner-Jeffreys et al. 2004). Thus, in lieu of the negative impacts of antibiotics on aquaculture, there is an urgent need on the prudent use of antibiotics in pangasid catfish hatcheries and to control the bacterial flora in hatching pools and larval rearing tanks by other means.

\section{References}

APHA. 1992. Compendium of Methods for the Microbiological Examination of Foods. Vanderzent C, Splittstoesser DF, ed., American Public Health Association, Washington, DC, 1208pp.

Austin B, Austin DA. 2007. Bacterial Fish Pathogens: Diseases of Farmed and Wild Fish, $3^{\text {rd }}$ (revised) edition, SpringerPraxis, Godalming, 552pp.

Bhattacharya SK. 2008. Status of fisheries development in West Bengal. Fish Chimes 28(1), 80-82.

Blanch AR, Alsina M, Simon M, Jofre J. 1997. Determination of bacteria associated with reared turbot (Scophthalmus maximus) larvae. J Appl Microbiol 82, 729-734. doi:10.1046/j.1365-2672.1997.00190.x

Chattopadhyay NR. 2003. Fish breeding in captivity - some innovative adaptations of technology by Bengal farmers. Aquaculture Asia 8(2), 13-16.

Collins CH, Lyne PM, Grange JM. 1989. Microbiological Methods. $6^{\text {th }}$ Edition, Butterworths, London, UK, 409pp.

Dang LT, Tu DT, Kondo H, Hirono I, Aoki T. 2007. First determination of transferable antimicrobial resistance plasmids (R plasmids) in Edwardsiella ictaluri isolated from diseased freshwater catfish, Pangasius hypophthalmus (sauvage), in Vietnam. 13th International Conference of Fish and Shellfish Diseases, 17-21 September 2007, The European Association of Fish Pathologists, Grado, Italy. Abstract O- 038, p47.

Hansen GH, Strøm E, Olafsen JA. 1992. Effect of different holding regimens on the intestinal microflora of herring, Clupea harengus. larvae. Appl Environ Microbiol 58, 461-470.

Hansen GH, Olafsen JA. 1989. Bacterial colonization of cod (Gadus morhua L.) and halibut (Hippoglossus hippoglossus) eggs in marine aquaculture. Appl Environ Microbiol 55, 1435-1446.

Hansen GH, Olafsen JA. 1999. Bacterial interactions in early life stages of marine cold water fish. Microb Ecol 38, 1-26. doi:10.1007/s002489900158

Husevag B, Lunestad BT, Johanneessen PJ, Enger O, Samuelson OB. 1991. Simultaneous occurrence of Vibrio salmonicida and antibiotic-resistant bacteria in sediments at abandoned aquaculture sites. J Fish Dis 14, 631-640. doi:10.1111/j.13652761.1991.tb00621.x

Huys L, Dhert P, Robles R, Ollevier F, Sorgeloss P, Swings J. 2001. Search for beneficial bacterial strains for turbot (Scophthalmus maximus L.) larviculture. Aquaculture 193, 25-37. doi:10.1016/S0044-8486(00)00474-9 
Kha NHN, Sarter S, Legarve T, Montet D. 2006. Characterization of bacteria isolated from farmed catfish coming from Vietnam and study of their antibiotic resistance. Proc. International Workshop on Biotechnology in Agriculture, October 20-21, 2006, Nong Lam University Ho Chi Minh City, pp.103-108.

Lechevallier M, Seidler RJ, Evans TM. 1980. Enumeration and characterization of standard plate count bacteria in chlorinated and raw water supplies. Appl Environ Microbiol 40(5), 922-930.

MAF. 2008. Import Risk Analysis: Frozen, Skinless and Boneless Fillet Meat of Pangasius spp. Fish from Vietnam for Human Consumption. Biosecurity New Zealand, Ministry of Agriculture and Forestry, Wellington, New Zealand, 70p.

Mallick PK. 2008. Freshwater Catfish Diseases and their Management. M F Sc Thesis, West Bengal University of Animal and Fishery Sciences, Kolkata, 130pp.

Olafsen JA. 2001. Interactions between fish larvae and bacteria in marine aquaculture. Aquaculture 200, 223-247. doi:10.1016/S0044-8486(01)00702-5

Palumbo SA, Maxino F, Willams AC, Buchanan RL, Thayer DW. 1985. Starch-ampicillin agar for the quantitative detection of Aeromonas hydrophila. Appl Environ Microbiol 50, 1027-1030.

Sarkar UK, Paul SK, Kapoor D, Deepak PK, Singh SP. 2006. Captive breeding of pangasid catfish Pangasius pangasius with Ovaprim - an attempt towards sustainable seed production and conservation of wild populations. Aquaculture Asia 11(3), 9-10.

Subagja J, Slembrouck J, Hung LT, Legendre M. 1999. Larval rearing of an Asian catfish Pangasius hypophthalmus (Siluroidei, Pangasiidae): Analysis of precocious mortality and proposition of appropriate treatments. Aquat Living Resour 12, 37-44. doi:10.1016/S0990-7440(99)80013-8

Sugita H, Miyajima C, Deguchi Y. 1991. The vitamin B12-producing ability of the intestinal microflora of freshwater fish. Aquaculture 92, 267-276. doi:10.1016/0044-8486(91)90028-6

Verner-Jeffreys DW, Shields RJ, Bricknell IR, Birkbeck TH. 2004. Effects of different water treatment methods and antibiotic addition on larval survival and gut microflora development in Atlantic halibut (Hippoglossus hippoglossus L.) yolk-sac larvae. Aquaculture 232, 129-143. doi:10.1016/S0044-8486(03)00525-8 